\title{
GIRLS WIN COMPUTERS IN LATIN OLYMPIAD
}

Five out of six top Latin pupils in the country are girls, but boys were also well represented at the S.A. Classical Association's Latin Olympiad prizewinners' party held in the Michaelis Gallery in Cape Town on Friday evening (13 August).

The top standard 10 pupil is Nicky Rome of King David High, Victory Park, Johannesburg, who won a colour computer presented by Mr Emest Walker of Mustek Electronics, Cape Town. Runners-up were Carolyn Maxwell of Pietermaritzburg Girls' High and Jacques Simmons of King David High, Linksfield, Johannesburg, who were presented with University study bursaries of R1000 and R750 respectively. In standard 9 the lucky recipient of a computer from ComputerValue, Ottery, Cape Town was Caroline Shackleford of Durban Girls' College, Orange Grove. Kelly Bayer, also from King David at Linksfield, came second, and the runner-up was Catherine de Souza, St. Mary's School for Girls', Highlands North. They also received bursaries.

The six finalists were flown to Cape Town and all spent a happy week-end exploring Cape Town as the guests of Southern Sun's Inn on the Square. Their chaperone was CASA-WP Committee member Diane Jorge. On the Saturday they were shown around Cape Town's Victoria and Alfred Museum by CASA member Nigel Fawcett.

Latin seems to be the common denominator in a variety of interests. Two of these top six want to take up law, two want to study medicine or science. All agree that the intellectual stimulus Latin gives them is a good preparation for any career.

The Latin Olympiad is usually held in alternate years, with separate competitions for standards nine and ten. Between them the six represent a wide range of talents. Candidates in the second national Latin Olympiad came from all over the country. Their home languages ranged from Afrikaans to Zulu. The Olympiad has shown that Latin is a good foundation for much more than law or medicine. The over 200 Olympiad candidates between them had plans for about thirty different career choices, from accountancy and architecture to dentistry and library science.

\section{ACKNOWLEDGEMENTS}

CASA gratefully acknowledges the magnificent gift of computer systems, from Mr Etienne Hucq of ComputerValue of Ottery, and Mr Emest Walker of Mustek Electronics of Cape Town, also the continued contribution of Academica Books of Pretoria, Van Schaik and University Booksellers-HAUM of Stellenbosch, Book Promotions of Claremont and Trustbank Stellenbosch. The book firms awarded a number of books as prizes for runnersup, as well as contributing substantially to the scholarship fund. Second and third prizes in each standard are University Scholarships. The contribution of the Cecil Jowell Family Trust to the air tickets is much appreciated. CASA offered as many prizes as possible, to encourage senior Latin pupils of all ability levels to participate.

Dr. J.M. Claassen, Olympiad-facilitator 